УДК 94(479.24)

DOI: $10.21779 / 2542-0313-2019-34-3-13-20$

\title{
И.Ф. Аласов
}

\section{История становления новых прикаспийских стран}

Ярославский государственный университет им. П.Г. Демидова; Россия, 150003, 2. Ярославль, ул. Советская, 14; alasov_imam@mail.ru

В статье показаны место и роль Азербайджана, занимающего центральную позицию в геополитике по отношению ко всем остальным участникам каспийской пятерки на континенте. Азербайджан рассматривается как один из ключевых субъектов среди каспийской пятерки, граничащий со всеми остальными участниками, от которого зависит геоэкономическая и геополитическая стабильность всей Евразии. Азербайджан является центром геополитического транзитного коридора «Шелковый путь» прикаспийских стран. Распад СССР на Каспии создал геополитические проблемы, нежели экономические плюсы. России приходится считаться с остальными членами каспийской четверки, чьи экономические и политические интересы не совпадают. Повышенный геополитический потребительский интерес стран Европы и США делает Каспийский регион ещё более проблематичным.

Ключевые слова: Азербайджан, Российская Федерачия, ЕC, раздел Каспия, геополитический коридор.

Каспийское море, расположенное на Евразийском континенте, представляет собой самый крупный на планете замкнутый водоем. С точки зрения географии, это озеро (бессточный водоем, не соединенный с морями и океаном), но практически Каспий считается морем (из-за сильной солености воды и больших размеров). Площадь моря составляет около 371 тыс. кв. км, максимальная глубина - 1025 м. Не имея естественного выхода к Мировому океану, Каспийское море не подпадает под действие Международных конвенций по морскому праву ООН.

В историческом, политическом, культурном и географическом отношении Каспийское море имеет богатую и древнюю историю - (Хəzər dənizi). В современное время на геополитическом и на геоэкономическом уровне его значимость возросла многократно. Каспийский водоем - единственное озеро на планете, соединяющее между собой пять независимых государств, поэтому их внешняя политика строилась и строится с учетом интересов друг друга. Кроме того, Каспийский регион является своего рода мостом между Европой и Азией. Макроэкономика Каспийского моря не может не интересовать мировое сообщество, прежде всего ЕС и США, ввиду наличия энергетических ресурсов и мировых запасов осетра (90\%).

Использование ресурсов Каспийского моря привлекло международное внимание ведущих стран Запада, США и КНР прежде всего из-за географического положения коридора «Азия-Европа». Не будет преувеличением сказать, что коридор между Востоком и Западом проходит именно через Каспий в виде «Великого шелкового пути».

Каспийское море имеет глобальный геоэкономический и геополитический статус на Евроазиатском континенте. С образованием новых суверенных государств на пост- 
советском пространстве после распада СССР сложилась новая ситуация, отличительной чертой которой было возрастание роли государств региональных стран.

Нефтегазовые ресурсы Каспийского моря разными экспертами оцениваются в пределах 18-20 млрд тонн условного топлива, а доказанные запасы составляют примерно 4 млрд тонн. Данная статистика позволяет сделать вывод, что Каспийское море занимает второе место в мире по объему запасов нефти и газа после Персидского залива.

Ещё после Каспийского похода Петра I море впервые вошло в границы Российской империи (персидские районы Гилян, Мазендеран и Астрабад, расположенные на южном берегу). Однако эти границы часто менялись из-за конфликтов между Персией и Россией, особенно после смены в 1723 г. династии Сефевидов Иранского Азербайджана на Каджаров (Надир-шах). Двести лет назад Российская империя практически управляла Каспийским морем. По Гюлистанскому мирному договору, заключенному после русско-персидской войны 1804-1813 гг., ей было предоставлено исключительное право иметь военный флот на Каспии. Туркманчайский мирный договор, завершивший войну России с Персией 1826-1828 гг., подтвердил это условие, а Иранский Азербайджан (Персия) был лишен подобного договора (ст. 8 Договора). Данный Договор действовал вплоть до 1917 года [1, с. 12].

28 февраля 1921 г. правительство РСФСР подписало договор с Иранским Азербайджаном, по которому отменялись все соглашения, заключенные царским правительством, в т. ч. и Туркманчайский договор 1828 года, признавалось право Ирана на свободное плавание по Каспийскому морю. Вопрос о разграничении вод Каспийского моря в Договоре не ставился ${ }^{1}$.

В годы существования СССР освоение Каспийского моря регулировалась советско-иранскими договорами от 1921 и 1940 гг., в которых предусматривались свобода судоходства по всей акватории моря и свобода рыболовства по принципу «общей воды» за исключением десятимильных национальных рыболовных зон. Данный правовой режим, установленный советско-иранскими договорами, действовал до принятия нового соглашения по статусу Каспия. В послевоенные годы Каспийская флотилия продолжала играть роль стабилизирующего фактора в Азербайджанской ССР, ставшей ее главной базой (Баку).

В 1970 году Министерство нефтедобывающей промышленности СССР разделило дно советской части Каспийского моря между прибрежными республиками, причем за основу была взята срединная линия. После распада СССР центр Российской флотилии был перебазирован из Баку в Астрахань и Махачкалу.

С получением независимости союзными республиками и прекращением существования СССР число прикаспийских государств увеличилось до пяти. Береговая линия приобрела следующий вид: Азербайджан на юге-западе - 955 км; Казахстан на востоке и северо-востоке - 2320 км; Туркмения на юге-востоке - 1200 км; Иран на юге 724 км; Россия на северо-западе и западе - 695 км (Астраханская область, Дагестан и Калмыкия). Возникла необходимость принятия нового соглашения о правовом статусе Каспийского моря, разработка которого была инициирована азербайджанской стороной. Ещё 18 января 1991 г. Совет министров Азербайджанской ССР и Миннефтегазпром СССР совместным заявлением уточнили секторальную границу между Азербайджанской и Туркменской ССР. Лидеры прикаспийских стран справедливо указывали на

\footnotetext{
${ }^{1}$ Договор между РСФСР и Персией от 26 февраля 1921 года // Хрестоматия по истории России с древнейших времен до наших дней / сост. А.С. Орлов и др. - М., 2000 (далее - Договор, 2000).

14

Вестник Дагестанского государственного университета

Серия 2. Гуманитарные науки. 2019. Том 34. Вып. 3
} 
то, что советско-иранские договоры затрагивают далеко не все аспекты правового статуса Каспия, не опираются полностью на инструменты современного международного права. В частности, в сфере морского права международно-правовые акты появились лишь в 1958 и 1982 гг. (Женевская конвенция о континентальном шельфе и Конвенция ООН по морскому праву) [2, с. 2].

С распадом СССР новым суверенным странам СНГ пришлось самостоятельно выстраивать национальный внешнеполитический курс с учетом новых международных, экономических и политических реалий. Дезинтеграция Советского Союза создала уникальную возможность для Азербайджана сыграть роль своеобразного геостратегического коридора между Востоком и Западом, между доминирующей на севере Россией и ее извечными конкурентами в Закавказье - Турцией и Ираном. Действительно, представить Евразийский коридор без участия Азербайджана было бы просто невозможно. Но верно и то, что реализация любых международных проектов в Каспийском регионе зависела от России, Турции и Ирана. Если в их политике взяли бы верх гегемонистские тенденции, то регион оказался бы во власти их противоречивого соперничества, что затруднило бы решение многих проблем. Однако у Азербайджана были преимущества перед другими новообразованными государствами на постсоветском пространстве. Вопервых, стратегическое расположение на Каспийском море - на границе с Россией, Ираном, Туркменией, Казахстаном, а по существу ещё и с Турцией, Грузией, Арменией. Во-вторых, главное богатство азербайджанских недр - нефть и газ - привлекало внимание бизнесменов и политиков всего мира. Азербайджан становится ключевой страной в евразийском коридоре [3, с. 15].

Учитывая выгодное геостратегическое положение Азербайджана среди пяти прикаспийских стран, США и государства ЕС всегда стремились (и стремятся) повлиять на политику Баку в своих интересах. В свое время советник Президента США Д. Картера (1977-1981 гг.) по национальной безопасности, небезызвестный профессор 3. Бжезинский говорил об Азербайджане как о сердце Кавказско-Каспийского региона. «Несмотря на ограниченные территориальные масштабы и незначительное по численности население, - подчеркивал он, - Азербайджан с его огромными энергетическими ресурсами - это пробка в сосуде, содержащем богатства Каспийского моря и Средней Азии» [4, c. 300-301].

Среди политико-экономических проблем, сложившихся вокруг Каспия, пожалуй, самым значимым являлся вопрос (не решенный и до сих пор) о правовом статусе.

Среди прикаспийских государств Азербайджан ещё в 1991 г. первым заявил о секторальном разделе Каспийского моря, по которому каждая страна будет владеть водной территорией на основе исключительного права. Этой позиции власти Азербайджана придерживаются и до сего дня, утверждая, что прилегающие к нему дно и водное пространство Каспия являются полностью национальным сектором. Данная норма закреплена и в Конституции Азербайджанской Республики.

В свою очередь руководство Казахстана с 1991 г. в определении юридического статуса Каспия придерживалось схожих с «азербайджанским вариантом» позиций, хотя и с некоторыми оговорками: Каспий не может быть признан ни морем, ни озером. В первом случае территориальные воды (200 миль) будут перекрываться друг другом (наибольшая ширина Каспия - 435 км), что также приведет к исчезновению «открытого моря», и соответственно судоходство и рыболовство станут невозможны по тем же причинам. Во втором случае это чрезмерно затрудняет судоходство и рыболовство, поскольку будет связано с пересечением границ суверенных государств. При этом казах- 
станская сторона игнорировала российские предложения о возможности введения 45-мильной зоны территориальных вод.

В самом начале 1990-х гг. РФ, занятая выработкой своей внешнеполитической линии в отношении США и ЕС, не уделяла внимания Каспийскому региону. Свою роль сыграли чеченский и армяно-азербайджанский конфликты. Однако следует признать, что Российская Федерация с момента распада СССР всегда выступала против раздела Каспийского моря на национальные сектора и за использование его богатств на основе многосторонних соглашений, не ущемляющих права и интересы ни одного из прибрежных государств, за создание региональной организации прикаспийских государств. Также оказал влияние и географический фактор, так как Азербайджан и Россия являются транзитным географическим коридором в поставке своих энергоресурсов до потребителя. Отсюда транзитная зависимость других нефтегазовых прикаспийских стран (Туркмении, Казахстана, Ирана) от Азербайджана [5, с. 152].

С начала 1992 г. Азербайджан начал вести переговоры с иностранными нефтяными компаниями для разработки проекта и вложения инвестиций в энергетическую сферу азербайджанского сектора.

В сентябре-октябре 1994 г. правительством России были приняты жесткие меры по срыву всех контрактов для разработки Каспийского шельфа. В заявлении посольства РФ в Баку говорилось, что «в последнее время Азербайджан, Казахстан и Туркмения предпринимают настойчивые попытки заключить контракты с западными корпорациями в целях освоения дна Каспийского моря. 12 сентября 1994 г. МИД РФ направил МИД Азербайджана ноту, согласно которой «...односторонние действия в отношении Каспия являются незаконными и не будут признаваться Российской Федерацией, которая оставляет за собой право принять такие меры, которые будут необходимы, и в то время, которое она сочтет подходящим для восстановления нарушенного правопорядка. Вся ответственность, включая возможный материальный ущерб, ляжет на тех, кто предпринимает односторонние действия, проявляя тем самым пренебрежение к правовой природе Каспия, к своим обязательствам по международному праву» [6].

Заключенный в Баку 20 сентября 1994 г. «Контракт века» с 11 странами мира, который Азербайджан объявил своим «экономическим реваншем», категорически не совпадал с интересами Российской Федерации. Пользуясь азербайджанским вариантом, остальные прикаспийские страны, исключая Россию, также начали развивать свою нефтегазовую добычу на Каспии. Кроме того, Азербайджаном и Туркменией приняты законодательные акты, направленные на присвоение обширных каспийских пространств. Указанные действия несовместимы с действующим правовым режимом и ущемляют права и интересы России [7, с. 4].

Аналогичные ноты были направлены посольствам Казахстана и Туркмении. В них указывалось, что Россия будет проводить жесткую политику в случае принятия одностороннего действия в отношении Каспийского моря и вся ответственность ляжет в рамках международных норм на прикаспийские страны [8, с. 7].

В свое время азербайджанский общенациональный лидер, президент страны, а также один из бывших советских партийных лидеров Г. Алиев заявил о том, что «Контракт века» является результатом осознанной внутренней и внешней политики Азербайджанского государства. Он также является и результатом установления принципов рыночной экономики в Азербайджане, интеграции нашей страны в систему международных экономических отношений и политики, проводимой государством по привлечению зарубежных инвестиций в Азербайджанскую Республику [9, с. 256]. 
Фундамент «Контракта века» был заложен ещё раньше процессами демократического строительства в Азербайджане проводимой президентом Азербайджана Г. Алиевым политикой открытых дверей - неуклонной и последовательной нормализацией и стабилизацией внутриполитической обстановки в стране.

Однако следует отметить, что Российская Федерация фактически ранее признала секторальный раздел Азербайджана на Каспии на правительственном уровне. Еще 20 ноября 1993 г. по инициативе самой России между правительствами Азербайджана и Российской Федерации, с участием министра топлива и энергетики Ю. Шафраника по поручению премьера В. Черномырдина было подписано соглашение «О сотрудничестве в области разведки и разработки нефтяных и газовых месторождений на территории Азербайджанской Республики» [10, с. 776].

Словами «азербайджанский сектор» в тексте Соглашения признавалась территория, закрепленная за Азербайджаном. После подписания Соглашения, с началом нового этапа переговоров по созданию международного консорциума, Россия была вовлечена в переговорный процесс. С российской стороны единственной нефтяной компанией, включенной в список «Контракта века», был «Лукойл», получавший 10 \% прибыли от доли «нефтяного лакомства». Контракт, заключенный между «Лукойлом» и ГНКАР, давал правомерный повод властям Азербайджана заявить, что этот документ о совместной разработке шельфа в азербайджанском секторе Каспийского моря подписан с участием двух сторон.

Только после заключения «Контракта века» Российская Федерация заявила, что нефтяные договоры Азербайджана с другими странами ущемляют интересы остальных прикаспийских стран. Иными словами, все договоры и соглашения, связанные с Каспийским морем, должны согласовываться с остальными участниками каспийской пятерки. Таким образом, спор о правовом статусе Каспийского моря вышел на новый уровень.

Однако, несмотря на «мягкую» позицию главы правительства России в этом вопросе, МИД страны продолжал свою «жесткую» политику по отношению к Азербайджану. В начале октября 1994 г. МИД России распространил очередные документы, касающиеся каспийской проблемы, которые обязывали прикаспийские страны соблюдать экологию в рамках Международных правовых норм Каспийского бассейна. В них также говорилось, что азербайджанским гражданским и военным судам запрещается пользоваться водными путями в России, а также заявлять о праве собственности на нефтяное оборудование, имеющееся на Каспии. Позиция МИД России была поддержана службой внешней разведки: ее руководитель Е. Примаков заявил, что нефтяной контракт представляет собой угрозу национальной безопасности России [11, с. 4].

8 октября 1994 г. на сессии Генеральной Ассамблеи ООН Российская Федерация своим официальным докладом уведомила, что если ее позиция относительно правового статуса Каспия не будет признаваться легитимной в одностороннем порядке всеми прикаспийскими странами, то она «оставляет за собой право принять такие меры, которые будут необходимы, как и то время, которое она сочтет подходящим для восстановления нарушенного правопорядка и ликвидации последствий, возникших в результате односторонних действий» [12, с. 384].

Несмотря на жесткую политику МИД РФ по вопросу о возможности допуска западных нефтяных компаний к ресурсам Каспия в российском секторе (у побережья Дагестана) с участием нефтяных российских компаний «Лукойл», «Роснефть» и британской нефтегазовой компании JKX, все-таки была создана Каспийская совместная ком- 
пания по разработке нефтяных месторождений. Данное соглашение также было негативно оценено и Государственной Думой РФ. В июне 1995 г. первый заместитель председателя ЛДПР, заместитель председателя Госдумы А. Венгеровский в письменном обращении к Совету безопасности России отмечал, что «расширяющееся присутствие Запада на Каспии выходит далеко за пределы экономических интересов и явно начинает приобретать антироссийскую направленность» [13, с. 280].

В свою очередь Азербайджан придерживался исключительно жесткой позиции только секторальный раздел. Он объявил прилегающий к государству участок Каспия полностью национальным сектором, закрепил это положение в Конституции страны и начал активно осваивать свой сектор. При этом за основу в Баку была взята т. н. «линия Черномырдина», утвержденная 9 ноября 1995 г. и одобренная распоряжением Правительства РФ № 1564-р «О проекте Договора между Правительством Российской Федерации и Правительством Азербайджанской Республики о транзите азербайджанской нефти через территорию Российской Федерации» за подписью премьер-министра В. Черномырдина. В нем отмечается: «Согласиться с предложением Минтопэнерго России и МИД России, согласованным с Минфином России, Минэкономики России, МВЭС России, Минсотрудничеством России, Минюстом России и ГТК России о проведении Минтопэнерго России и Минсотрудничеством России с участием других вышеуказанных органов исполнительной власти переговоров с Азербайджанской стороной по обсуждению прилагаемого проекта Договора между Правительством Российской Федерации и Правительством Азербайджанской Республики о транзите азербайджанской нефти через территорию Российской Федерации, разрешив при проведении переговоров отступать по отдельным вопросам, не затрагивающим его принципиальных положений». И далее: «Правительство Российской Федерации и Правительство Азербайджанской Республики, именуемые далее Сторонами, учитывая положения Договора к Энергетической Хартии от 17 декабря 1994 г., стремясь к дальнейшему укреплению добрососедских отношений, желая развивать двустороннее экономическое сотрудничество на основе взаимной выгоды, принимая во внимание стремление Азербайджанской Республики развивать надежные и эффективные пути транспортировки азербайджанской нефти на международные рынки, стремясь обеспечить благоприятные условия для транспортировки азербайджанской нефти через территорию Российской Федерации, договорились о следующем...» [14, с. 101].

Проблемные отношения выстраивались у Азербайджана с Ираном и Туркменистаном. Так, между Азербайджаном и Туркменистаном возникли серьезные разногласия относительно границы секторов: последний считал месторождение Азери полностью находящимся на его территории, а Чираг - частично. Что же касается Ирана, то, находясь в глубокой экономической изоляции со стороны США и ЕС, Тегеран стремился заручиться поддержкой России в своей борьбе за снятие торговых ограничений или, по крайней мере, ослабить их за счет развития двусторонних связей с Россией.

Однако Россия, Иран и Туркменистан, ориентируясь на работу создаваемой ими компании в «секторах» трех стран, подчеркивали, что речь идет не о «национальных секторах», а о «прибрежных зонах» этих государств. Россией была предложена компромиссная основа для решения правовых вопросов вокруг Каспия: ограничение юрисдикции прибрежных государств в отношении разработки углеводородного сырья 45-мильной прибрежной зоны с сохранением находящейся за пределами этих участков центральной части моря для совместного освоения. В этом случае ширина центральной части Каспия между 45-мильными зонами составила бы от 20 до 90-30 миль. 
В новой политике Российской Федерации геостратегическое и экономическое значение Азербайджана в Каспийском регионе не вызывает сомнений. Таким образом, в целях развития двустороннего взаимовыгодного экономического сотрудничества Азербайджанской Республики с Российской Федерацией для транспортировки азербайджанской нефти транзитом через территорию России на международные рынки, 18 января 1996 года в Москве был подписан Договор между Российской Федерацией и Азербайджанской Республикой о транзите азербайджанской нефти через территорию Российской Федерации [10, с. 259-262].

Соответственно для развития двусторонних отношений между Россией и Азербайджаном нужно активизировать стратегию в области освоения азербайджанских углеводородных месторождений и транзита нефтегазовых ресурсов по территории России. Учитывая геополитический баланс в современном мире, на постсоветском пространстве и вокруг прикаспийских стран, на фоне резкого усиления противостояния между Западом и Россией и борьбы за раздел сфер международного влияния на Каспии, крайне возросла политическая, экономическая, геостратегическая, энергетическая транзитная роль Азербайджана в новом тысячелетии во внешней политике России. Сегодня можно констатировать, что, несмотря на нерешенность проблемы статуса и раздела Каспия, страны каспийской пятерки установили тесные политико-экономические взаимоотношения.

\section{Литература}

1. Агаева Хураман. Özümüzü və dünyani dərketmə yolunda. Сборник научных статей. - Баку, 2011.

2. Назарбаев Н. Как нам поделить Каспий // Известия. - 2003. - 3 окт.

3. Берлс Р. Стратегические размышления относительно стран Кавказа // Capital. 1997. - Сент.

4. Озеров М. Ильхам Алиев: Я верю в мой Азербайджан. - М.: Бослен, 2007.

5. Курбанов Я.Н. Международное экономическое сотрудничество в освоении углеводородных ресурсов Каспия: дис. ... канд. эк. н.: 08.00.14. - М., 2006. - 161 с.

6. Независимая газета. - 1994. - 29 окт.

7. Московские новости. - 1994. - 25 окт.

8. Независимая газета. - 1994. - 29 сент.

9. Гафар Мамед оглу Алиев. Основоположник, спаситель и созидатель современного Азербайджана. - Бишкек: Мегамедия, 2008.

10. Сборник документов. МИД Российской Федерации. МИД Азербайджанской Республики. Azerbaycan - Rusiya / Россия - Азербайджан (1992-2012). - Баку, 2012.

11. Независимая газета. - 1994. - 29 сент.

12. Гусейнов В. Каспийская нефть. Экономика и геополитика. - М.: Олма-Пресс, 2002.

13. Андрианов А., Мираламов Г. Гейдар Алиев. - М.: Молодая гвардия, 2005.

14. Мир Ахмад Голамали. Роль Каспийского моря во взаимоотношениях прибрежных государств: дис. ... канд. ист. н.: 07.00.15. - Душанбе, 2015.

\section{References}

1. Agayev Huraman. Özümüzü və dünyani dərketmə yolunda. Collection of scientific articles. - Baku, 2011. - 12 p.

2. Nazarbayev N. How to divide the Caspian Sea // Izvestia. - 2003. - October 3rd. 
3. Berls R. Strategic reflections on the countries of the Caucasus // Capital. - 1997. September.

4. Ozerov M. Ilham Aliyev: I believe in my Azerbaijan. - M., 2007. S. 300-301.

5. Kurbanov I.N. International economic cooperation in the development of hydrocarbon resources of the Caspian Sea: Dis. ... kand. Ec. Sciences: 08.00.14. - M., 2006. - $161 \mathrm{~s}$.

6. Independent newspaper. - 1994. - 29 Oct.

7. Moscow news. $-1994 .-25$ Oct. -4 p.

8. Independent newspaper. - 1994. - September 29th. -7 p.

9. Gafar Mamed oglu Aliyev. Founder, Savior and Creator of modern Azerbaijan. Bishkek, 2008. - $256 \mathrm{p}$.

10. Collection of documents. The Ministry of foreign Affairs of the Russian Federation. The Ministry of foreign Affairs of the Republic of Azerbaijan. Azerbaycan / Rusiya Russia Azerbaijan (1992-2012). - Baku. - 2012. - P. 776.

11. Independent newspaper. - 1994. - Sept. 29th. - P. 4.

12. Huseynov V. Caspian oil. Economics and geopolitics. $-384 \mathrm{p}$.

13. Andrianov A., Miralamov G. Heydar Aliyev. - M.: Young guard, 2005. - 280 p.

14. World of Ahmad Gholamali. The role of the Caspian Sea in the relations of coastal States: Dis. ... kand. east. Sciences: 07.00.15. - Dushanbe, 2015. - P. 101.

Поступила в редакиию 15 сентября 2019 г.

UDC 94(479.24)

DOI: $10.21779 / 2542-0313-2019-34-3-13-20$

\title{
The history of the new Caspian countries' formation
}

\begin{abstract}
I.F. Alasov
Yaroslavl State University. P.G. Demidova; Russia, 150003, Yaroslavl, Sovetskaya st., 14; alasov_imam@mail.ru

The article shows the place and role of Azerbaijan, playing a leading role in the geopolitics in relation to all the other members of the Caspian five on the continent. Azerbaijan is considered as one of the key players among the five Caspian countries, bordering on all other participants. Geoeconomic and geopolitical stability across Eurasia also depends on Azerbaijan being the center of a geopolitical corridor of the silk road Caspian countries. The collapse of the USSR in relation to the situation with the Caspian countries has created more geopolitical problems rather than the economic advantages. Russia has to reckon with the other members of the Caspian Quartet, where economic and political interests do not coincide. The increased geopolitical interest of consumer countries in Europe and the United States make the Caspian region even more problematic.
\end{abstract} corridor.

Keywords: Azerbaijan, Russian Federation, EU, Section of the Caspian Sea, geopolitical Received 15 September, 2019 